\title{
PENGARUH KONSENTRASI IBA (Indole Butyric Acid) DAN LAMA PENCELUPAN STEK TERHADAP PERTUMBUHAN GERMINATIF RUMPUT RAJA (Pennisetum purpurephoides)
}

\author{
Ch. W. Patty * \\ Jurusan Peternakan Fakultas Pertanian, Universitas Pattimura \\ Jln. Ir. M. Putuhena, Kampus Poka, Ambon 97233 \\ *Email : ch.patty@gmail.com
}

\begin{abstract}
ABSTRAK
Rumput raja adalah tanaman berumur panjang yang pertumbuhan awalnya lambat bila dibandingkan dengan rumput gajah. Pertumbuhan dan perkembangan bibit tanaman ditentukan oleh cepat lambatnya pertumbuhan mata tunas dan sistim perakaran. Oleh karena itu dalam mengusahakannya perlu diperhatikan hal-hal yang menyangkut perangsangan terhadap pertumbuhan germinatif dari rumput raja tersebut. Penelitian bertujuan untuk mengetahui pengaruh tingkat konsentrasi IBA dan lama pencelupan stek terhadap pertumbuhan germinatif rumput raja. Penelitian menggunakan rancangan Acak Lengkap Pola Faktorial 3 x 3 . Perlakuan dalam percobaan ini adalah $\mathrm{K}_{1}$ (konsentrasi $100 \mathrm{ppm}$ ), $\mathrm{K}_{2}$ (konsentrasi 200 ppm), $\mathrm{K}_{3}$ (konsentrasi $300 \mathrm{ppm}$ ), W $\mathrm{W}_{1}$ (lama pencelupan 1 jam), $\mathrm{W}_{2}$ (lama pencelupan $2 \mathrm{jam}$ ) dan $\mathrm{W}_{3}$ (lama pencelupan 3 jam). Hasil penelitian ini memperlihatkan bahwa antar perlakuan memberilkan pengaruh yang tidak nyata terhadap persentase pertunasan, jumlah tunas, tinggi tanaman, jumlah akar, panjang akar. Namun ada kecendrungan semakin tinggi tingkat konsentrasi yang diberikan semakin baik hasilnya. Tingkat konsentrasi IBA dan lama pencelupan stek berpengaruh positif, dimana dari rataan yang diperoleh $\mathrm{K}_{3} \mathrm{~W}_{3}$ memberikan persentase muncul tunas, tinggi tanaman dan panjang akar tertinggi. Sedangkan persentase muncul tunas, jumlah tunas, tinggi tanaman dan panjang akar terendah terdapat pada $\mathrm{K}_{1} \mathrm{~W}_{1}$.
\end{abstract}

Kata kunci: Rumput raja, konsentrasi IBA, lama pencelupan, pertumbuhan germinatif

\section{THE EFFECT OF IBA (Indole Butyric Acid) CONCENTRATION AND IMMERSION PERIOD OF THE PLANT CUTTING ON THE GERMINATION GROWTH OF KING GRASS (PENNISETUM PURPUREPHOIDES)}

\begin{abstract}
King grass is parenenial plant that grow slower then elephant grass. The growth and development of the plant breed effected by development of the clone so that some efforts must be taken to stimulate germinative development of king grass. The research purposed to know how for the level of IBA consentration and immersion period of the slip of plant has an effect toward the growth of germination of king grass. Complete randomizet design of factorial type $3 \times 3$ and Duncan's multiple range test, were used in the experiment. The treatments were used in the eksperiment: $K_{1}\left(100 \mathrm{ppm}\right.$ of concentration), $\mathrm{K}_{2}$ (200 ppm of concentration), $\mathrm{K}_{3}(300 \mathrm{ppm}$ of concentration), $\mathrm{W}_{1}$ (one hours of immersion period), $\mathrm{W}_{2}$ (two hours of immersion period), $\mathrm{W}_{3}$ (Three hours of immersion period). The result of this research showed that amount the treatments gave significant effect to the percentation of buds, number of buds, height of plant, number of roots, length of root. Nevertheless, there was an inccclination that the more the height of consentration level was given, the result would better than the research. It can be concluded that the level of IBA consentration and immersion period had a positive effect influences which from the average result obtained $\mathrm{K}_{3} \mathrm{~W}_{3}$ gave the heighest percentation of buds appear, number of buds, height of plant and length of roots. While persentation of buds to appear, number of buds, height of buds and the lowest roots length founded in $\mathrm{K}_{1} \mathrm{~W}_{1}$.
\end{abstract}

Key words: King grass, IBA concentration, immersion period, growth of germination

\section{PENDAHULUAN}

Upaya peningkatan produktivitas ternak ruminansia, diperlukan hijauan yang tersedia sepanjang tahun, berkualitas baik dan penanamannya mudah. Bahan pakan hijauan memegang peranan istimewa karena merupakan sumber makanan utama bagi ternak ruminansia untuk dapat bertahan hidup dan 
berproduksi. Produksi ternak yang tinggi perlu didukung oleh ketersediaan pakan hijauan yang cukup dan kontinu (Suryana, 2009). Sumber utama pakan hijauan adalah berasal dari rumput, salah satunya adalah rumput raja (Pennisetum purpurephoides), yang sudah menyebar ke seluruh pelosok tanah air karena mempunyai beberapa keunggulan seperti produksi hijauannya tinggi yaitu mencapai 1.076 ton rumput segar/ha/tahun (Suyitman, 2014), umur panen pendek dan kandungan zat makanannya tinggi (Siswanto dkk., 2016).

Rumput raja mempunyai pertumbuhan awal lebih lambat bila dibandingkan dengan rumput gajah. Oleh karena itu dalam mengusahakan tanaman ini perlu diperhatikan hal-hal yang menyangkut perangsangan terhadap pertumbuhan germinatifnya. Pertumbuhan dan perkembangan bibit tanaman ditentukan oleh cepat lambatnya perkembangan mata tunas dan sistem perakaran. Perkembangan mata tunas berkaitan dengan penyediaan energi untuk pertumbuhan, sedangkan sistem perakaran erat hubungannya dengan absorbsi air dan unsur hara (Nababan, 2009).

Salah satu cara untuk memperbaiki pertumbuhan akar adalah menambahkan zat pengatur tumbuh auksin ke dalam media tumbuh. Beberapa jenis auksin dapat diaplikasikan bersama-sama atau dikombinasikan dengan zat pengatur tumbuh golongan sitokinin dan gibberellins (Ahmed et al., 2002), tetapi untuk menginduksi perakaran, lebih baik hanya dengan penambahan satu jenis auksin saja (George dan Sherrington, 1984).

Auksin adalah jenis hormon tumbuh yang disintesis oleh tanaman, berperan mengatur pertumbuhan dan perkembangan tanaman, termasuk inisiasi akar lateral dan respon gaya gravitasi (Chun et al., 2003) dan berfungsi sebagai katalisator dalam metabolisme serta berperan dalam perpanjangan sel (Alrasyid dan Widiarti, 1990). Auksin sintetis yang sering digunakan untuk menginduksi perakaran tanaman in vitro adalah Napthalene Acetic Acid (NAA) dan Indole Butyric Acid (IBA) (Dodds and Roberts, 1995).

Menurut Wattimena (1998) dan Sandra (2010) fungsi auksin sintesis seperti (IBA dan NAA) adalah menginduksi kalus, mendorong perpanjangan sel, pembelahan sel, differensiasi jaringan xilem dan floem, penghambatan mata tunas samping, absisi (pengguguran daun), aktivitas kambium, dan pembentukan akar atau tunas. Auksin mendorong terjadinya pembelahan sel, sehingga dibutuhkan untuk pembentukan akar (Davies, 1995). Penambahan auksin pada media tumbuh tidak selamanya meningkatkan jumlah akar, karena penambahan auksin jenis tertentu dengan konsentrasi tertentu menurunkan jumlah akar (Fuchs, 1986). Respon pertumbuhan akar dan tunas plantlet sangat bergantung pada konsentrasi auksin dan waktu aplikasi (Ashburner and Thompson, 1993).
Indole Butyric Acid (IBA) adalah zat pengatur tumbuh tanaman yang sudah banyak diperdagangkan dan dipergunakan dalam bidang pertanian. Pemakaian IBA lebih efektif dari zat pengatur tumbuh lainnya karena kandungan kimianya lebih stabil dan daya kerjanya lama sehingga dapat memacu pembentukan akar, serta fleksibel dalam hal kepekatan. IBA yang diberikan pada stek akan tetap berada pada tempat pemberiannya sehingga tidak menghambat pertumbuhan dan perkembangan tunas (Ramadiana, 2008). Pemakaian IBA sebagai zat pengatur tumbuh tanaman yang mengandung auksin dalam beberapa penelitian telah menunjukan respons yang bermanfaat pada tanaman seperti apel, karet, mawar, rumput pangila, lada, buah naga (Shofiana dkk., 2013), dan pala (Heryana dan Supriadi, 2011).

Salah satu metode yang dipakai untuk mengaplikasikan zat pengatur tumbuh sintesis seperti IBA adalah metode pencelupan, dimana jumlah yang dapat terserap masuk ke dalam stek tergantung dari konsentrasi IBA dan waktu pencelupannya. Konsentrasi IBA yang terserap oleh stek tanaman apabila terlalu tinggi akan menghambat pertumbuhan stek itu sendiri. Penelitian ini dilaksanakan dengan tujuan untuk mengetahui penggunaan IBA dengan tingkat konsentrasi dan lamanya pencelupan stek yang berbeda terhadap pertumbuhan germinatif rumput raja (Pennisetum purpurephoides).

\section{BAHAN DAN METODE}

Penelitian ini dilaksanakan di kebun Hijauan Makanan Ternak Jurusan Peternakan Universitas Pattimura dan berlangsung selama tiga (3) bulan. Peralatan yang digunakan dalam penelitian ini adalah peralatan pertanian (seperti ayakan, cangkul, ember), mistar ukur/meteran, dan alat tulis menulis. Bahan yang digunakan adalah stek rumput raja, larutan IBA, dan tanah sebagai media tanam. Stek rumput raja yang digunakan dalam penelitian ini berasal dari rumput yang telah tumbuh sempurna. IBA (3-Indole butyric acid) sebagai zat pengatur tumbuh.

Rancangan yang digunakan adalah percobaan Faktorial dalam Rancangan Acak Lengkap (RAL) 3 x 3 dengan tiga ulangan. Setiap ulangan terdapat tujuh stek. Dimana tingkat konsentrasi IBA sebaga faktor $\mathrm{K}$ $(\mathrm{K} 1=100 \mathrm{ppm}, \mathrm{K} 2=200 \mathrm{ppm}, \mathrm{K} 3=300 \mathrm{ppm})$ sedangkan lama pencelupan stek sebagai faktor $\mathrm{W}$ $(\mathrm{W} 1=1 \mathrm{jam}, \mathrm{W} 2=2 \mathrm{jam}, \mathrm{W} 3=3 \mathrm{jam})$. Untuk mengetahui beda masing-masing tingkat perlakuan terhadap pertumbuhan rumput raja dipakai uji jarak dari Duncan. Stek rumput raja yang telah disiapkan dimasukkan ke dalam ember yang telah diisi dengan larutan IBA sesuai dengan konsentrasinya dan lama pencelupan. tergantung pada perlakuan yang dilaksanakan, kemudian stek langsung ditanam pada bedengan dengan jarak $50 \times 50 \mathrm{~cm}$.

Variabel yang diamati dalam penelitian ini adalah adalah : a) waktu pertunasan, b) jumlah tunas, 
c) tinggi tanaman, d) jumlah akar, dan e). panjang akar. Semua variabel pengamatan dihitung dan diukur satu kali setiap minggu, kecuali untuk jumlah dan panjang akar dilakukan pada akhir penelitian.

\section{HASIL DAN PEMBAHASAN}

Pembahasan ini didasarkan pada pengaruh masing-masing faktor perlakuan yang dicobakan, terhadap komponen pertumbuhan germinatif rumput raja yang dapat dilihat pada Tabel 1 .

Hasil pengamatan yang diperoleh menunjukan bahwa perbedaan tingkat konsentrasi IBA dan lama pencelupan stek memberikan pengaruh yang tidak nyata terhadap waktu pertunasan dan jumlah tunas per stek rumpur raja. Namun ada dugaan pertumbuhan komponen tunas yang meliputi persentase munculnya tunas dan jumlah tunas menunjukan bahwa konsentrasi IBA 300 ppm $\left(\mathrm{K}_{3}\right)$ dan lama penculupan 3 jam $\left(\mathrm{W}_{3}\right)$ adalah yang terbaik dari semua perlakuan serta perlakuan kontrol yang ada. Hal ini menunjukan bahwa IBA dapat merangsang pembentukan pembentukan tunas pada rumput raja. Wattimena (1988) menyatakan bahwa hormon yang mengawali reaksi biokimia dan mengubah komposisi di dalam tanaman, sebagai akibat pengubahan komposisi kimia terjadi pembentukan organ-organ tanaman seperti akar, tunas, daun, bungan dan lainlain. Hal ini sejalan dengan hasil penelitian Gardner et al. (1985) bahwa perakaran tanaman sangat terhambat di atas kisaran optimum konsentrasi auxin. Oleh karena itu, konsentrasi auksin untuk mendorong pembesaran sel pada akar lebih rendah dibanding dengan konsentrasi auksin untuk mendorong pertumbuhan batang (Davies et al., 1986).

Tabel 1. Rataan muncul tunas, jumlah tunas per stek, tinggi tanaman, jumlah akar per stek, dan panjang akar rumput Raja (Pennisetum purpurephoides) pada pertumbuhan germinatif.

\begin{tabular}{|c|c|c|c|c|c|}
\hline Perlakuan & $\begin{array}{c}\text { Muncul tunas (\%) } \\
\text { TN) }\end{array}$ & $\begin{array}{l}\text {.Jumlah tunas } \\
\text { per stek }^{\mathbf{T N})}\end{array}$ & $\begin{array}{l}\text { Tinggi tanaman } \\
(\mathrm{cm})^{\mathrm{TN})}\end{array}$ & $\begin{array}{l}\text { Jumlah akar per } \\
\text { stek }^{\text {TN) }}\end{array}$ & $\begin{array}{l}\text { Panjang akar } \\
(\mathrm{cm})^{\text {TN })}\end{array}$ \\
\hline K1W1 & 77,87 & 9,71 & 80,91 & 27,43 & 55,14 \\
\hline K1W2 & 80,00 & 10,33 & 85,00 & 28,19 & 56,86 \\
\hline K1W3 & 86,67 & 9,2 & 88,36 & 29,24 & 63,43 \\
\hline $\mathrm{K} 2 \mathrm{~W} 1$ & 82,22 & 10,38 & 81,14 & 26,48 & 56,52 \\
\hline $\mathrm{K} 2 \mathrm{~W} 2$ & 86,67 & 10,48 & 86,24 & 27,57 & 61,34 \\
\hline K2W3 & 88,89 & 10,28 & 88,48 & 27,62 & 65,24 \\
\hline K3W1 & 86,67 & 10,91 & 84,05 & 26,43 & 61,90 \\
\hline K3W2 & 88,89 & 12,29 & 87,91 & 27,34 & 67,62 \\
\hline K3W3 & 91,11 & 10,28 & 89,33 & 27,47 & 69,24 \\
\hline Kontrol & 68,89 & 7,86 & 64,83 & 17,09 & 39,91 \\
\hline
\end{tabular}

Keterangan : ${ }^{\mathbf{T N})}$ pengaruh perlakuan tidak nyata (p-value $\left.>0,05\right)$

Hasil uji statistik menunjukkan terdapat pengaruh yang tidak nyata terhadap tinggi tanaman. Dari nilai rataan yang diperoleh menunjukan bahwa konsentrasi IBA yang tinggi memberikan hasil yang semakin baik. Diduga IBA selain dapat merangsang pertumbuhan tunas baru juga dapat merangsang pemanjangan sel. Prawiranata $d k k$ (1989) dalam Purwaningsih (1992), menyatakan bahwa hormon dapat merangsang pertumbuhan tunas terminal, dengan demikian terjadi proses pemanjangan batang tanaman.

Hasil pengamatan menunjukan bahwa konsentrasi dan lama perendaman IBA mempunyai pengaruh yang tidak nyata terhadap komponen akar, namun dari hasil yang diperoleh ternyata untuk variabel panjang akar perlakuan $\mathrm{K}_{3} \mathrm{~W}_{3}$ menunjukan hasil yang terbaik. Sedangkan untuk banyak akar perlakuan $\mathrm{K}_{1} \mathrm{~W}_{3}$ menunjukan hasil yang terbaik. Diduga peningkatan konsentrasi IBA yang dipakai sejalan dengan meningkatnya panjang akar yang dihasilkan namun menurunkan jumlah akar yang dibentuk. Hal ini menggambarkan IBA lebih berfungsi untuk memanjangkan akar dari pada memperbanyak akar. Hal ini sesuai dengan pendapat Kusumo (1990) bahwa hormon mempunyai pengaruh yang berbeda pada banyak akar maupun kualitas akar yang dihasilkan. Adanya pengaruh yang berbeda-beda ini disebabkan rendahnya zat pengatur tumbuh yang diaplikasikan pada rumput raja. IBA yang dalam jumlah sedikit dapat merangsang pertumbuhan akar, ternyata dalam konsentrasi tersebut responnya lebih bersifat memanjangkan akar daripada membentuk sel akar baru. Delvin (1975) dalam Abidin (1989) menyatakan bahwa pemberian konsentrasi hormon yang relatif tinggi pada akar, akan menyebabkan terhambatnya perpenjangan akar tetapi meningkatkan jumlah akar. Pertumbuhan akar sangat menentukan pertumbuhan dan produktivitas tunas. Menurut Rochiman dan Harjadi (1973) dalam Tupan (1990) menyatakan bahwa makin cepat dan bayak jumlah akar yang terbentuk, akan memungkinkan pertumbuhan bibit yang lebih baik, besar dan kuat. Hal ini disebabkan karena makin cepat dan banyak akar yang terbentuk akan lebih mendorong 
pembentukan tunas pada stek, serta meningkatkan absorbs air dan hara yang lebih baik bagi pertumbuhan bibit.

IBA yang diaplikasikan sebenarnya merupakan zat perangsang untuk perakaran, sehingga yang diharapkan dari pemakaian senyawa ini adalah terjadinya perangsangan pada komponen perakaran dari rumput raja tersebut. Namun dari hasil penelitian ternyata ada keseimbangan pertumbuhan antara akar dan tunas. Hal ini menunjukan bahwa dalam proses pertumbuhan ada hubungan timbal balik antara keduanya. Menurut Bonner dan Galston (1952) dalam Tupan (1990) menyatakan bahwa untuk pertumbuhan sistem perakaran, daun dan tunas secara mutlak diperlukan adanya substansi-substansi kimia tertentu selain karbohidrat. Untuk pertumbuhan akar mutlak diperlukan adanya thanian, pirydoksin dan asam nikotin yang dibentuk di daun. Sedangkan untuk pertumbuhan daun diperlukan purin, adenine dan hypoksatin yang dibentuk di akar.

Hasil penelitian menunjukkan bahwa IBA dengan konsentrasi tertingi (300 ppm) memberikan pertumbuhan yang terbaik pada persentase muncul tunas, jumlah tunas, tinggi tanaman dan panjang akar, walaupun hasil analisis statistik menunjukkan adanya yang tidak nyata. Hal ini menunjukan keberhasilan suatu zat pengatur pertumbuhan pada suatu jenis tanaman dipengaruhi oleh banyak faktor selain konsentrasi IBA yang digunakan dan lama pencelupan. Meskipun hasil penelitian yang diperoleh memperlihatkan adanya pengaruh yang tidak nyata dari penggunaan IBA dengan konsentrasi dan lama pemcelupan berbeda, perlu kiranya dalam penelitian ini diberi sekilas gambaran manfaat dan cara IBA dalam memberikan pengaruh terhadap pertumbuhan germinatif rumput raja. Odum (1971) dalam Tupan (1990) mengemukakan bahwa pertumbuhan dan perkembangan tanaman dipengaruhi oleh faktor lingkungan dan faktor tanaman itu sendiri, serta interaksi antara kedua faktor tersebut. Selanjutnya dikatakan bahwa penggunaan hormon sintesis yang diaplikasikan pada tanaman dapat mengatur pertumbuhan dan perkembangan tanaman melalui pengaruh tidak langsung. Pengaruh secara tidak langsung dapat terjadi antara lain melalui daya kerja di dalam mengadakan perangsangan terhadap sintesis protein dan hormon-hormon endogen. Dengan cara mengikat membran protein sehingga enzim-enzim yang terbentuk menjadi aktif. Aktifitas ensim meningkatkan plastisitas dan pelebaran dinding sel yang menyebabkan terjadinya proses tumbuh dari tanaman tersebut. Delvin (1975) dalam Abidin (1989) menyatakan bahwa fungsi auksin dalam sintesis protein berkaitan dengan pembebasan DNA dari histone untuk sintesa mRNA. Selanjutnya mRNA mambantu dalam pembentukan enzim-enzim baru yang sangat berperan dalam pembentukan protein. Enzim-enzim ini akan meningkatkan plastisitas dan extention (pelebaran) dinding sel. Enzim-enzim tersebut adalah invertase, pectin methylesterse, dan ascorbic acid oxidase.

\section{SIMPULAN}

Konsentrasi IBA 100 ppm, 200 ppm dan 300 ppm dengan lama pencelupan 1 jam, 2 jam dan 3 jam tidak memberikan perbedaan yang nyata antar perlakuan yang diberikan. Dari hasil yang diperoleh bahwa tingkat konsentrasi IBA dan lama pencelupan stek berpengaruh positif, dimana dari rataan yang diperoleh $\mathrm{K}_{3} \mathrm{~W}_{3}$ memberikan persentase muncul tunas, tinggi tanaman dan panjang akar tertinggi. Sedangkan persentase muncul tunas, jumlah tunas, tinggi tanaman dan panjang akar terendah terdapat pada $\mathrm{K}_{1} \mathrm{~W}_{1}$.

\section{DAFTAR PUSTAKA}

Abidin, Z. 1989. Zat Pengatur Tumbuh. Jambi: Balai Informasi Pertanian Jambi.

Ahmed, E.E., G.Y.D. Bisztray, and I. Velich. 2002. Plant regeneration from seedling explants of common bean (Phaseolus vulgaris L.). Proceedings of the $7^{\text {th }}$ Hungarian Congress of Plant Physiology. p. 115-123. BudapestHungarian: Szent Istvan University of Budapest.

Alrasyid, H., dan A. Widiarti. 1990. Pengaruh Penggunaan Hormon IBA terhadap Persentase Hidup Stek Khaya anthoteca. J. Balai Penelitian Hutan. 523: 1-22. Bogor: Pusat Penelitian dan Pengembangan Kehutanan Bogor.

Ashburner, G.R., and W.K. Thompson. 1993. Coconut Embryo Culture for Internasional Transfer of Germplasm. Proceedings of the International Symposium on Coconut Research and Develomant II. Kasaragod, India.

Chun, T., S. Taketa, S. Tsurumi, and M. Ichii. 2003. The effects of auxin on lateral root initiation and root gravitropism in a lateral rootless mutant Lrt1 of rice (Oryza sativa). Plang Growth Regulation. 39: 161-170.

Davies, P.J. 1995. Plant Hormones: Physiology, Biochemistry and Molecular Biology. p. 1-33. Dordrecht/ Boston/London: Kluwer Academy Publishers.

Davies, W.J., J. Metcalfe, T.A. Lodge and A.R. da Costa. 1986. Plant Growth Substances and the Regulation of Growth under Drought. Aust. J. Plant Physiol. 13:105-125.

Dodds, H.J., and L.W. Roberts. 1995. Experiments in Plant Tissue Culture. p. 255. Cambridge: Cambridge University Press. 
Fuchs, H.W.M. 1986. Plant Regeneration of Rose Plants as Influnced by Applied Auxin. Acta Horticulture. 189: 13-19. Netherlands: Netherlands Agricultural University, Departement of Horticulture.

Gardner, F.P., R.B.Pearce, and R.L. Mitchell. 1985. Physiology of crop plants. First edition. 50010. p:156-186. Ames, Iowa: The Iowa State University Press.

George, E.F., and P.D. Sherrington. 1984. Plant Propagation by Tissue Culture. Handbook and Directory of Commercial Laboratories. p.4287; p.184-227. UK, England: Exegetics Ltd.

Heryana, N., dan H. Supriadi. 2011. Pengaruh indole butyric acid (IBA) dan naphthalene Acetic acid (NAA) terhadap keberhasilan grafting tanaman pala. Buletin RISTRI. 2(3): 279-284.

Kusumo, S. 1990. Zat Pengatur Tumbuh Tanaman. Jaklarta: Penerbit CV. Yasaguna.

Nababan D, 2009. Penggunaan Hormon IBA terhadap Pertumbuhan Stek Ekaliptus Klon IND 48. http://repository.usu.ac.id/bitstream/12345678 9/7668/3/09E00911.pdf. [4/08/2019].

Purwaningsih, D. 1992. Pengaru IBA dan Lama Perendaman Benih Terhadap Pertumbuhan Bibit Jambu Mete (Anocardium occidentale). [Tesis]. Ambon: Fakultas Pertanian, Universitas Pattimura.

Ramadiana, S. 2008. Respon Pertumbuhan Stek Lidah Mertua (Sansevieria trifasciata var. Lorentii) pada Pemberian Berbagai Konsentrasi IBA dan Asal Bahan Tanam. http:// www.unila.ac.id/jurnal/
jurnal_natur/vol6\%281\%29/Ramadiana.pdf. [4/08/2019].

Sandra, E. 2010. Peranan zat pengatur tumbuh dalam kultur jaringan. Jakarta: Esha Flora.

Shofiana, A., Y.S. Rahayu, dan L.S. Budipramana. 2013. Pengaruh pemberian berbagai konsentrasi hormon IBA (indole butyric Acid) terhadap pertumbuhan akar pada stek batang tanaman buah Naga (Hylocereus undatus). LenteraBio. 2(1): 101-105.

Siswanto, D., B. Tulung, K. Maaruf, M.R. Waani, dan M.M. Tindangen. 2016. Pengaruh pemberian rumput raja (pennisetum purpupoides) dan tebon jagung terhadap kecernaan NDF dan ADF pada sapi PO pedet jantan. Jurnal Zootek. 36(2): 379 - 386.

Suryana. 2009. Pengembangan usaha ternak sapi potong berorientasi agribisnis dengan pola kemitraan. Balai Pengkajian Teknologi Pertanian Kalsel. Jurnal Litbang Pertanian. 28 (1): 29-36.

Suyitman. 2014. Produktivitas rumput raja (pennisetum purpupoides) pada pemotongan pertama menggunakan beberapa sistem pertanian. Jurnal Peternakan Indonesia. 16(2): 119-127.

Tupan, J.A. 1990. Penentuan cara meletakkan BIT Pisang dan Tingkan Konsentrasi NAA Terhadap Pertumbuhan Bibit Pisang di Pesimaian. [Tesis]. Ambon: Fakultas Pertanian, Universitas Pattimura.

Wattimena, G. A. 1988. Zat Pengatur Tumbuh Tanaman. Bogor: Laboratorium Kultur Jaringan, PAU Bioteknologi, IPB.

Available online at journal homepage: http://ojs3.unpatti.ac.id/index.php/agrinimal 